\title{
Tradition of "Pasang Ri-Kajang" in the Forests Managing in System Mores of "Ammatoa" at District Bulukumba South Sulawesi, Indonesia
}

Erman Syarif

PPS Universitas Negeri Malang , Email: emankgiman@gmail.com

Ach. Fatchan

Universitas Negeri Malang (correspondent),Email: ach.fatchan.fis@um.ac.id

Sumarmi

Universitas Negeri Malang, Email: sumarmi.fis@um.ac.id

I Komang Astina

Universitas Negeri Malang, Email: I.Komang.Astina.fis@um.ac.id

Doi:10.5901/mjss.2016.v7n6p325

Abstract

Pasang Ri-Kajang is part of the culture in customs Ammtaoa in Bulukumba, South Sulawesi. Customs that contains the ethics and norms related to forest management. The purpose of this study are: (1) describe the forms of customs Ammatoa manage forests in Pasang Ri-Kajang tradition, and (2) describe the patterns of action to preserve forests in the customs Ammatoa. This study used a qualitative approach with a knife phenomenological analysis. Locations of research in Bulukumba and research subjects are people and community leaders perpetrators forest conservation. The data collection is done by observation, depthinterview and documentation. To control the validity of the data using the technique of triangulation, member check and audit trail. The results of the research showed: (1) people believe taking care of forests is an obligation. This was in line with the tradition of Pasang Ri-Kajang. Where the forest is an area that is holy, sacred, and have supernatural powers; (2) The action of society treats forests as: borong karamaka (sacred forests or protected forests), borong batasayya (limited production) and borong luarayya (community forests). The pattern of such acts are influenced by their kasipalli (prohibition destroying forests), especially sacred forests. If there is a violation, then sanctioned and banned from indigenous Ammatoa. As a result of the application of the tradition and the rules consistently, then the forest in Bulukumba be stable until now.

Keywords: Forest management, Pasang Ri-Kajang, and customs Ammatoa

\section{Background}

Current forest management many failures due to lack of care and lack of law enforcement (Hidayat, 2010). Salim (2014) noted that the causes of forest destruction is caused by illegal logging, forest fires and forest land conversion. The main cause of deforestation in Indonesia is to meet the needs of everyday life in the communities around the forest. Communities meet the needs of everyday life regardless of the nature/forests in the vicinity (Aryadi, 2000). Therefore, we need a policy that involves communities in forest management. Forms of community involvement, among others linking local knowledge to maintaining the forest. The aim, among others, in order to be sustainable forests and forest degradation can be reduced. As we know that forest destruction in Indonesia increased high. For example: in 2015 in Indonesia forest area of 130.61 million hectares. And of the total $7 \%$ of them damaged by felled. If averaged about $3 \%$ of Indonesia's forests are reduced in each year. Other data related to the destruction of forests, as issued by the Forest Wacth Indonesia (FWI) in 2015. Where the rate of Indonesian forest destruction figures for the period 2009-2014 was 4.6 million hectares per year. Furthermore, Arief (2001) revealed that the damaged forest reached 43 million hectares or 33\% of Indonesia's forest area. Deforestation rate of about 1.6 million hectares per year.

Specifically, deforestation occurred in South Sulawesi also showed high numbers. South Sulawesi Provincial Forestry Office noted that the deforestation rate in 2014 reached $30.60 \%-40.00 \%$. The spread of forest destruction include: 
conservation forest $20.34 \%$, of the forest $50.21 \%$, limited production forest $22.06 \%$, fixed production forest $4.86 \%$ and convertible production forest $2.63 \%$. Based on data from the Forestry Research Institute in Makassar, South Sulawesi forest on the extent of 3,879,771 hectares (Ministry of Forestry, 2012). Where the forest area tends to decrease every year. For example, in 2012 the condition of forests in South Sulawesi decreased 10.6\%. While in 2013 decreased 30.6\% (Forest Watch Indonesia, 2015). The forest area reduction caused by various factors, among others: illegal logging, forest encroachment activities and mining activities.

One form of saving the forest in order to remain sustainable existence is to involve local wisdom. They include the existence of local knowledge of culture, traditions and values of local people's lives. The involvement of local wisdom as has been done by previous researchers as a reinforcement of the implementation of the education sector (Belinda, 2012; Fatchan, Amirudin, and Soekamto, 2015; Fatchan, Soekamto, and Mustafa, 2015). As we know that local knowledge is formed through a process of interaction between man and his environment (Ministry of Environnment, 2004; Qandhi, 2012). This was done by the people because he wanted to meet the various needs of life. Local knowledge as the knowledge, confidence, understanding, customs and ethics that guide human behavior in life (Keraf, 2002). Local knowledge is important to be studied, maintained, and used as a filter in the entry of a change in the era of globalization. Specifically in Southern Sulawesi, forms of local wisdom that is "Pasang Ri-Kajang". In the perspective of anthropology Ahmad (2007) noted that the "pasang" as an absolute element in the belief system of the "Kajang". Ibrahim (2001) noted that " pasang" is a "verbal message that must be followed, complied with and implemented". Replace as something "sacred" because if it is not implemented in our daily activities have a negative impact in the form of the destruction of the ecological balance and chaotic social systems. Ammatoa indigenous people in South Sulawesi province Bulukumba call "Pasang Ri-Kajang" (Ramly, 2012).

On the one hand, the condition of forests in South Sulawesi suffered significant damage. However, on the other hand, the existing forests in indigenous communities Bulukumba. Ammatoa in South Sulawesi province remain stable, even better. Such phenomena need to be revealed holistically, why it happened. Previous research on the phenomenon has been carried out such as: Research Yakib (2003) which found that forest conservation Kajang indigenous communities caused by people who cling to the principle of Pasng Ri-Kajang and Tallase Kamase-Mase. Research Lureng (1991) Pasang RiKajang as a legacy of the traditional values of the ancestors who preserved until now. Tradition is, until today still exist and upheld by indigenous peoples in environment manage by Ammatoa. Ammatoa community still retains Kajang customary rules used to manage the environment. To maintain the beautiful environment requires awareness and ethical care for the environment by the public. One way to control environmental damage, among others, the development of environmental ethics in society (Salim, 2014). The goal is to be able to change the attitudes and behavior of humans (Sumarmi, 2014). Furthermore, Geertz (1992) noted that the ethics of good society will produce human morals, wise and prudent. Therefore, humans must take responsibility to preserve the natural environment.

Based on the description above, then this research are to understand holistically Ammatoa indigenous peoples in forest management based on tradition of Pasang Ri-Kajang. Thus, the purpose of this study are: (1) describe the forms of customs Ammatoa manage forests in Pasang Ri-Kajang tradition, and (2) to describe the pattern and meaning of action to preserve forests in the customs Ammatoa in the tradition of Pasang Ri-Kajang.

\section{Research Methods}

This type of research is qualitative by using the phenomenological approach. Phenomenological approach holds that a human action that contains a lot of meaning. Where the meaning is behind the phenomenon called "noumena". Each person's actions always contain something that is "unique" in line with the culture and traditions that exist in society itself. Implementation of this study followed the steps of qualitative research (Fatchan, 2013). Furthermore, the understanding taxonomically to find themes or domains. In gathering information, researchers examined the informant is to do with the question of non-structural and structural measures to uncover the perpetrators of environmental sustainability. The location of this research in Kajang, Bulukumba, South Sulawesi Province, Indonesia. The subjects were the traditional leaders and the perpetrators of forest preservation in Kajang-Bulukumba. Subjects selected in this research are: head of customs (Ammatoa), Galla Puto (Stakeholders custom), Galla Pantama (Stakeholders custom), Galla Kajang (Stakeholders customs), the village chief Tana Towa, Head Kajang, Indigenous peoples Ammatoa. Collecting data using observation, interview and documentation search. Checking the validity of the data using the technique of data triangulation, member check and audit trail. Analysis of data using interactive models as suggested by Miles and Hubermans (1997). 


\section{Result}

\subsection{The shape of the customs Ammatoa manage forests on the tradition Pasang Ri-Kajang}

For indigenous peoples in Kajang Bulukumba, establishment of forest areas have an important role for their survival. Because in everyday life they are linked and dependent on the forest around him. As explained in a customary rule that "forest that is the heritage of us". Based on observations and in-depth interviews show that in the environment of indigenous peoples Ammatoa there are three types of forest grouping. Forests in the local language in Bulukumba called with the word "borong". The third class of the forest is: the borong karamaka, borong batasayya, and borong luarayya. Furthermore, it can be explained that the indigenous forests in the study area showed extensive enough that 1,300 hectares. Of the forest area can be divided into: Forests of Karamaka area of 331.17 hectares (25.47\%), Batasayya forest area of 380.15 hectares (29.25\%) and forest of Luarayya area of 588.68 hectares (45.28\%). The spread of the forest types can clearly be seen as the first map below.

Borong Karamaka (sacred forest or protected forest) are forest areas off-limits to all types of activities, with the exception of activities or rituals. According to pasang, this forbidden forest (kasipalli) to enter, disrupt the flora and fauna present in the forest, their belief that the forest is a place of descent Tu Rie A'ra'na, the residence of the ancestors (pammantanganna sikamma tau rioloanta), and as Ammatoa induct place. Kind of gross violations in the region Borong Karamaka among others: Ta'bang Kaju (cut timber), Rao Doang (taking shrimp), Tatta 'Uhe (taking rattan), and Tunu Bani (burn bees).

Borong Batasayya (forest frontier or limited production forest) is an allowable forest along the wood supply timber is still there and with the permission of Ammatoa as indigenous leaders. Wood was present in the forest is only allowed to build public facilities, and to the community Ammatoa who can not afford to build a house. Aside from that goal, it will not be allowed. Only a few types of wood that may be harvested, the wood Asa, Nyatoh and Pangi. Violations in Borong Batasayya region, such as cutting down without the permission Ammatoa or log more than the permitted, will be subject to sanctions.

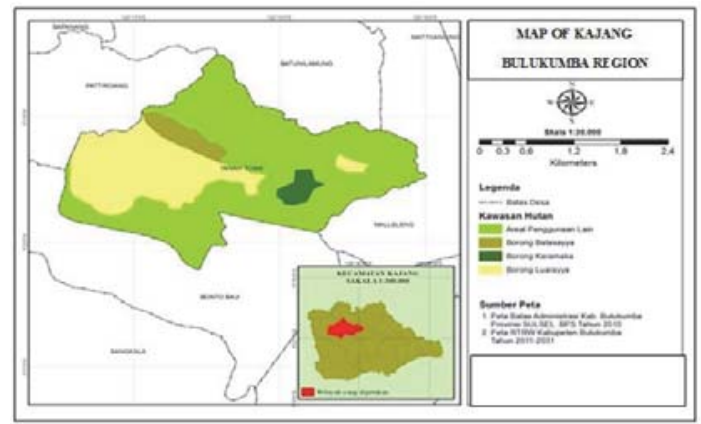

Map 1: Indigenous Forest in Region of Kajang-Bulukumba

Borong Luarayya (extensive woodland/forest People) are forests that can be managed by the community. Although Borong Luarayya controlled by the people, rules/sanctions customary in this region are still valid and are not allowed any practice of arbitrariness in exploiting the natural resources contained in Borong Luarayya. These lands are utilized by indigenous peoples Ammatoa to meet the needs of their daily lives. Furthermore, the forms of customs Ammatoa manage forests in the tradition of Pasang Ri-Kajang as shown in the following matrix 1.

Matrix 1: Ammatoa in Managing Forest in Pasang Ri-Kajang Tradition

\begin{tabular}{|l|l|ll|l|}
\hline No. & Informant & Information obtained & Themes found \\
\hline 1 & Head of customs & Kawasanga ada' ri Boronga ta'bange tallu,iamintu: & 3 division of forestry on \\
& & 1) & Borong Karamaka & Kawasanga ri boronga ni larang untu' iyangase jama-jamanga, \\
& & & \\
& & kecualia acara adaka. & \\
& & Borong Batasayya & \\
& & Boronga napakkuleanji nialle kajunna punna loheji kaju ni pa'rie & \\
& & & \\
\hline
\end{tabular}




\begin{tabular}{|c|c|c|c|}
\hline & & $\begin{array}{l}\text { Ammatoa. } \\
\text { 3) Borong Luarayya } \\
\quad \text { Boronga nakullea ni jama' masyaraka'a } \\
\text { Means: } \\
\text { Indigenous Forest Area is divided into three zones, namely: } \\
\text { 1) Borong Karamaka (Sacred Forest), the forest area off-limits to all } \\
\text { types of activities, with the exception of activities or rituals. } \\
\text { 2) Borong Batasayya (forest frontier), an allowable forest along the } \\
\text { wood supply timber is still there and with the permission of Ammatoa as } \\
\text { indigenous leaders. } \\
\text { 3) Borong Luarayya (community forests), the forest can be managed by } \\
\text { the community. }\end{array}$ & \\
\hline 2 & Head of customs & $\begin{array}{l}\text {-Anjo boronga anre nakkulle nipanraki. Punna nipanraki boronga, } \\
\text { nupanraki kalennu } \\
\text {-Anjo natahang ri boronga karana pasang. Rettopi tanayya rettoi ada' } \\
\text {-lya minjo boronga kunne pusaka. Talakullei nisambei kajua, iya to' } \\
\text { minjo kaju timboa, talakullei nitimbai nanikurangi borong karama, } \\
\text { nikasipalliangi tauwa a'lamung-lamung ri boronga, nasaba se're hattu } \\
\text { larie' tau angngakui bate lamunna. } \\
\text {-Kasipalli tauwa a'lamung - lamung ri boronga, } \\
\text { Nasaba' se're wattu la rie' tau angngakui bate lamunna } \\
\text { Artinya: } \\
\text {-Hutan 'keramat" itu tidak bisa ditambah atau dikurangi. Orang dilarang } \\
\text { menanam di dalam hutan } \\
\text { sebab suatu waktu akan ada orang yang mengakui bekas tanamannya. } \\
\text {-Hutan adalah "pusaka" kita. Tidak diperkenankan mengganti jenis kayu } \\
\text { di hutan adat, itu saja kayu yang tumbuh secara alami, tidak dapat } \\
\text { ditambah dan dikurangi, dilarang adanya kegiatan menanam di hutan } \\
\text { adat, sebab suatu waktu akan muncul pengakuan hak milik tanaman } \\
\text { dalam hutan adat tersebut. } \\
\text {-Hutan bisa lestari karena dijaga oleh adat. Bila bumi hancur, maka } \\
\text { hancur pula adat. } \\
\text {-Hutan tidak boleh dirusak. Jika engkau merusaknya, maka sama } \\
\text { halnya engkau merusak dirimu sendiri. }\end{array}$ & $\begin{array}{l}\text { Forest preservation, sacred } \\
\text { forest, the forest is the } \\
\text { heritage, customs and forest } \\
\text { health association }\end{array}$ \\
\hline 3 & Head of customs & $\begin{array}{l}\text { Anjo Atoranna ada'ka punna nia palanggaran ri boronga ta'bagei tallu } \\
\text { iamintu: pokok babbalak, tangnga babbalak siagang cappa babbalak. } \\
\text { This means: } \\
\text { Traditional sanctions when violations in the forest area is divided into } 3 \\
\text { parts: principal babbalak (the base of the whip), tangnga babbalak } \\
\text { (middle whip), and cappa babbalak (tip of the whip). }\end{array}$ & $\begin{array}{l}3 \text { Tier customary form of } \\
\text { sanctions for violators / forest } \\
\text { destruction }\end{array}$ \\
\hline 4 & $\begin{array}{l}\text { Indigenous } \\
\text { stakeholders }\end{array}$ & $\begin{array}{l}\text {-Punna erokko anna'bang sipoko' kayu ri boronga, a'lamunko rolo } \\
\text { ruang poko'anggenna timbo. } \\
\text { Nikasipalliangngi ammanra'-manrakia boronga } \\
\text {-Anjo borongnga iya kontaki bosiya, nasaba konre mae anre' } \\
\text { pangairang, iyaminjo borongnga selaku pangairang, nasaba iya } \\
\text { nakabattui bosi. } \\
\text { Means: } \\
\text {-If Want to cut down the tree trunk wood in the forest should be planted } \\
\text { the first two trees to grow well. } \\
\text {-Community forbidden forest destruction. } \\
\text {-forest that is coming of rain, because here there is no irrigation } \\
\text { (technical irrigation), then that's the forest that serves as irrigation, } \\
\text { because forest which causes rain }\end{array}$ & $\begin{array}{l}\text { Forest preservation and the } \\
\text { environment "beautiful" by } \\
\text { planting trees before felling }\end{array}$ \\
\hline 5 & $\begin{array}{l}\text { Indigenous } \\
\text { stakeholders }\end{array}$ & $\begin{array}{l}\text { Parakai Lino A'rurung Bonena } \\
\text { Kammaya Tompa Langika } \\
\text { Siagang Rupa Taua } \\
\text { Siagang Boronga } \\
\text { Means: } \\
\text { Take care of the earth and its contents } \\
\text { Similarly sky } \\
\text { Similarly to human } \\
\text { Similarly, forest }\end{array}$ & $\begin{array}{l}\text { Indigenous may preserving the } \\
\text { earth, particularly forests }\end{array}$ \\
\hline
\end{tabular}




\begin{tabular}{|l|l|l|l|}
\hline 6 & Formal figures & $\begin{array}{l}\text { Forests need to be preserved. Indigenous "Pasang Ri-Kajang" believe } \\
\text { that the source of life comes from the forest. Community forest } \\
\text { management rules based with still adhere to the provisions, } \\
\text { suggestions, prohibitions and sanctions. }\end{array}$ & $\begin{array}{l}\text { Preserving the forest, the } \\
\text { forest as a source of } \\
\text { community life }\end{array}$ \\
\hline 7 & Formal figures & $\begin{array}{l}\text { According to custom "Pasang Ri-Kajang" forests must be preserved. } \\
\text { Forests are part of life. Destroying the forest as well as self-destructive. }\end{array}$ & $\begin{array}{l}\text { Forest preservation based on } \\
\text { local customs. Destroying the } \\
\text { forest is self-destructive }\end{array}$ \\
\hline
\end{tabular}

Based on the findings of the data presented in the matrix 1 mentioned above, it can be built a new proposition as follows. The new proposition 1 is found:

Customs rules giving effect to the area and type of forest. Preservation of forests in the customary (pasang rikajang) is influenced by the firmness, continuity, obedience, and public awareness in complying with customary rules. Forest sustainability maintained due to the view that the forest is a part of life, is the heritage forest, and the forest is selfdestructive.

\subsection{The pattern and meaning of action to preserve forests in the tradition of Pasang Ri-Kajang}

As we know that forests exist within indigenous communities Bulukumba Ammatoa in South Sulawesi province remain stable and even better. Such a phenomenon implies that local traditions or local knowledge on people's lives tend to be concerned with the preservation of the forest environment. It has also been known in advance that the preservation of forests Kajang indigenous communities caused by people who cling to the principle of Pasang Ri-Kajang. That's because the Pasang Ri-Kajang as a legacy of the traditional values of the ancestors who preserved until now. Tradition is, until today still exist and firmly held by the public in Bulukumba. That's because people still maintain Ammatoa Kajang customary rules that are used in managing the forest environment. Found various meanings of why the Kajang in Bulukumba significantly always conserve forests. That meaning as revealed in this research. Various meanings that are shown in the matrix 2 below.

Matrix 2: Attach the meaning of Pasang Ri-Kajang on Forest Conservation

\begin{tabular}{|c|c|c|c|}
\hline No & Origional Pasang Ri-Kajang & No & Makna \\
\hline 1 & $\begin{array}{l}\text { Jagai linoa lollong bonena kammayya tompa langika siagang } \\
\text { rupa taua siagang boronga. }\end{array}$ & 1 & $\begin{array}{l}\text { Take care of the earth and its contents, as well as the sky, humans and } \\
\text { forests. }\end{array}$ \\
\hline 2 & $\begin{array}{l}\text { Anjo boronga iya kontaki bosiya nasaba konre mae } \\
\text { pangairangnga iaminjo boronga nikua pangairang. }\end{array}$ & 2 & $\begin{array}{l}\text { God is inviting the rain because here there is no irrigation, forests that serve } \\
\text { as irrigation due to bring rain. }\end{array}$ \\
\hline 3 & $\begin{array}{l}\text { Punna nitabbangngi kajua riborongnga, nunipappirangnga } \\
\text { Angngurangi bosi patanre timbusu. Nibicara pasang ri tau } \\
\text { Ma'riolo. }\end{array}$ & 3 & $\begin{array}{l}\text { If the wood in the forest is cut down, the rain will be reduced and the springs } \\
\text { will be lost (dries). Thus the message of our ancestors. }\end{array}$ \\
\hline 4 & Narie' kaloro battu riboronga, narie' timbusu battu rikajua. & 4 & $\begin{array}{l}\text { The existence of rivers originating frol } \\
\text { trees }\end{array}$ \\
\hline 5 & Boronga parallui nitallass & 5 & Forests need to be preserved because of the water coming from small rivers \\
\hline 6 & $\begin{array}{l}\text { lyamintu akkiyo bosi anggenna ereya nipake a'lamung pare, } \\
\text { ba'do appa'rie' timbusia. }\end{array}$ & 6 & $\begin{array}{l}\text { It (forest) which make rain so that it can be used to grow rice, corn and into } \\
\text { spring. }\end{array}$ \\
\hline 7 & $\begin{array}{l}\text { Anjo tugasa'na Ammatoa nalarangngi annabbang kaju ri } \\
\text { boronga. Iyaminjo nikua ada' tana. }\end{array}$ & 7 & $\begin{array}{l}\text { The task of a Ammatoa that prohibits the extraction of timber. Such laws } \\
\text { apply here. }\end{array}$ \\
\hline 8 & lyaminjo boronga kunne pusaka. & 8 & The forest is our heritage. \\
\hline 9 & $\begin{array}{l}\text { Talakullei nisambei kajua, iyato' minjo kaju timboa, talakullei } \\
\text { nitambai nanikurangi borong karama, nilarangngi tauwa } \\
\text { a,lamung-lamung riboronga, nasaba se're hattu larie' tau } \\
\text { angngakui bate lamunna. }\end{array}$ & 9 & $\begin{array}{l}\text { Not allowed to change the type of wood in the indigenous forest, just take the } \\
\text { wood that grows naturally, can not be added and subtracted, banned their } \\
\text { planting activities in indigenous forests, because a time will appear } \\
\text { recognition of property rights in indigenous forest plants. }\end{array}$ \\
\hline 10 & $\begin{array}{l}\text { Anjo boronga anre nakkule nipanraki. Punna nipanraki boronga, } \\
\text { nupanraki kalennu. }\end{array}$ & 10 & $\begin{array}{l}\text { Forests should not be tampered with, if you ruin it as well as the damage } \\
\text { yourself. }\end{array}$ \\
\hline 11 & Nikasipalliangngi ammanra'-manrakia boronga. & 11 & There are restrictions to the rules of forest destruction. \\
\hline 12 & $\begin{array}{l}\text { Anre nakulle ni Ta'bang kayu, tunu bani, Rao Doang siang tette' } \\
\text { Uhe'. }\end{array}$ & 12 & $\begin{array}{l}\text { It is strictly forbidden to cut down wood (trees), burned bees, catching shrimp } \\
\text { and cut down Rotan. }\end{array}$ \\
\hline 13 & $\begin{array}{l}\text { Boronga lya minjo kunne pusaka, anjo boronga } \\
\text { angngontaibosiya, aka'na kajua akkapaloppo timbusu. }\end{array}$ & 13 & The forest is our heritage, which bring rain forest, wood root enlarge springs. \\
\hline
\end{tabular}

Based on the findings of the data presented in the matrix 2 mentioned above, it can be built a new proposition as follows. The new proposition 2 is found:

Meaning of forest conservation measures in the local wisdom (traditional pasang ri-kajang) is related to the forest 
as part of human life. Preserving forests means means for the continuous rains. Forest preservation means to preserve water sources and caused agricultural businesses better. Forest conservation means acting to preserve the customs masyarakat.dalam refrain prohibited by customary.

\section{Discussion}

\subsection{The shape of the customs Ammatoa manage forests on the tradition Pasang Ri-Kajang}

The findings of this research indicate that the indigenous peoples Ammatoa adhere to the tradition Pasang Ri-Kajang (message rules in Kajang). Pasang Ri-Kajang used as a way of life every day. Such a finding clarify thesis Bromley (1989). He noted that the success of communities in forest management and use of forest resources depends on the degree of closeness of the relationship between communities and forest resources. Thus, this research makes it clear that shapes their relationship with their forest resources is shown the way of life of forest dwellers with the rules Pasang Ri-Kajang (message or advice that should be followed) in Kajang area.

The findings of this research is in line with the statement Adhan (2005). He explained that of the 120 rules, 83 of which contains a general rule, 24 contains rhymes and the arts, and 13 contain the environmental management system specifically indigenous forest. However, the findings of this research can explain in more detail about the meaning of "indigenous forest management" in contrast to previous research that only describes the general, who had not touched on the meaning, as the statement "meaning" conveyed by the following informant. As Ammatoa sense, "amma" means "father", "toa" means "elder". Him as "the elder" as a representative of the Lord shall have no obligation to maintain nature. It also has the task of maintaining and preserving the natural environment (forest) is based on the "rule" Pasang Ri-Kajang as the following statement.

The task of Ammatoa is to preserve the world and everything in it, including the linkages between people and forests. Ammatoa prohibit logging in the forest. That customary law. Forbidden to destroy forests (kasipalli). The requirement to maintain forest Ammatoa obligations, keep forests under sustainable conditions as in the existing rules (pasang). So the forest has been preserved. If a tree in the forest is cut down, it will reduce rainfall and eliminate the springs. Forests which bring rain, tree roots spring enlarge. It was like according to the messages of the ancients (ancestors).

In an effort to maintain the forests, Ammatoa lifting device 5 people in charge of indigenous forest guards. The custom devices namely: (1) Dalonjo in Balagana area, (2) Damangassalang in Balambina region, (3) Dagempa in the Deaf, (4) Dakodo in the area Teteaka, and (5) in the area Tumutung Sobbu. The fifth person in charge of maintaining the forest and report to Ammatoa in case of violation. Where if found those who damage the forest. Guard by the customary devices such as an effort to prevent people from destroying forests, but instead they are keeping. Rules and custody was in fact the "epitome" of it. Because fact of the community is very obedient to Ammatoa. They consciously act to maintain and be responsible for the preservation of their forests. Such obedience as has been found in previous research, especially in the world of vocational education in boarding schools (Susilo and Fatchan, 2014; Fatchan, Amirudin, Soekamto, 2015).

In the area of research shows that the public is well aware of the importance of forests for human life. That humans without forests would not be able to live a decent and healthy (Ramli, 2012). This is because trees and plants serve as a producer of oxygen (O2) that is needed by humans. Instead, carbon dioxide (CO2) emitted by human breath needed plants. The logic that causes communities and indigenous customs in force in the area of research must be maintained. Thus, the forest must be properly maintained in accordance with local customs in community life. Forests should receive special treatment for the residents and should not damage it.

In the act, a Ammatoa very firm in giving sanctions are customary when there are violations of forest destruction. Moreover, actions related to forest conservation are prohibited in customary rules. Decisive action in the form of traditional sanctions, such as sanctions that are excluded by custom. Actions which violate public mores considered an act that does not respect the environment. In a sense, the environment is supposed to be kept together and utilization wisely. The existence of trees in the forests are not overused, especially only for private purposes. Based peraaturan customary in the area of research, the provision of traditional sanctions are classified into three categories, namely (Akib, 2003): (1) a gross violation of (Principal Babbalak), (2) breach medium (Tangnga Babbalak) and (3) minor offenses (Cappa Babbalak).

First, heavy violation, if the violation is done in forest areas karamaka. The offense, such as if the person doing the logging in the forest. Penalties such violations in the form of "the base of the whip" (principal babbalak) or a fine in the form of money Rp. 800,000 and added a roll of white cloth. Second, the offense was, the offense being penalized to the 
person doing the logging in forest areas battasaya. Where the timber that exceeds a predetermined amount. Violations of this kind were awarded a penalty middle "whip" (tangnga babbalak) or fines with money as much as Rp. 400,000 coupled with a roll of white cloth. Third, minor violations, violations were given to a citizen because of negligence that cause wood in the forest area damaged. Damage was like uprooted, felled but not removed from its place, or cutting down trees in the garden but did not check beforehand. Such penalties against violators in the form of "tip of the whip" (cappa babbalak). Where is the equivalent of money of Rp 200,000 and coupled with a roll of white cloth.

\subsection{The pattern and meaning of action to preserve forests in the tradition of Pasang Ri-Kajang.}

According to Law No. 41 of 1999 on Forestry (Law of the Republic of Indonesia, 1999). Penalties forest destruction "illegal logging" stipulated in article 50 paragraph (3) letter e. The article reads: "felling trees, or harvest, or collect any forest products in the forest without any rights or permission of the Minister. Whoever intentionally violates the provisions referred to in article 50 paragraph (3) letter e punishable by a maximum imprisonment of 10 years and a maximum fine of Rp 5,000,000,000 (five billion rupiah). These laws are in line with customary rules applicable in the study area, although it seems lighter. As we know that the implementation of traditional sanctions in violation related to deforestation. Where serious violations, the large logging condemned "the base of the whip" and the money Rp. 800,000 and added a roll of white cloth. Violations were, cut timber that exceeds a predetermined amount middle "whip" or a fine of as much money as Rp. 400,000 coupled with a roll of white cloth. Light trespass, because negligence someone to cause tree damage punishment in the form of "tip of the whip", equivalent to Rp 200,000 and coupled with a roll of white cloth. This is in line with the findings Usop, where cutting down trees without permission rated as a serious violation, allowed one but two rated offense being cut down, and chop fine but not bring a including misdemeanors (Usop, 1998).

The form of sanctions mentioned above is a deterrent effect for offenders and forest destruction. That sort of thing is done Bulukumba indigenous communities, the goal that people truly understand the existence of forests in the region. That the importance of practice, act, and the natural environment and forests in line with the customs prevailing in the region. That sanctions for violations of the customs of the area is to be "definitely", there are customary rules, and are assertive, deserves punishment, and become effective. This can take place in the area Bulukumba caused by their participation pro-active citizens. Where they actively reported indigenous case of infringement.

What's interesting about this is that the research findings are made public distrust custom done by a traditional ceremony. The ceremony is a ceremony among others attunu panroli (burn crowbar) and burning "incense" (attunu passau). The traditional ceremony was intended to "measure" honesty and "convince" the sacred customs. As Puto Galla statement as follows: if there is a violation of the unknown culprit. Then the initiative Ammatoa (as customary head) perform traditional ceremonies. The ceremony was in the form of "ritual" which aims to reveal the meaning of truth, honesty, and trust. Forms ceremony of "ritual" is as follows: First, panroli attunu ceremony. The goal is to find out who is honest and who is dishonest among the people "perpetrators" of violations. Crowbar that had been burnt and become bright red. Furthermore, the alleged "perpetrator" was ordered to hold the crowbar. Who is right and to be honest did not feel the heat of the crowbar. Instead who is cheating and dishonest will feel the heat. Second, burning ceremony "incense" (attunu passau). The ceremony is conducted if the offender or offenders will escape punishment. "frankincense" burnt and accompanied by a reading of "spell" special. By performing such a ceremony, then the offender will be affected by the disaster in the form of sanctions "sacral". Sanctions "sacral" it's like a form of: stomach bloated, infected with leprosy, or dementia (mad) that can not be cured, even to death. Sanctions that are "sacred" is also found in the study of society "Osing" in Banyuwangi Indonesia (Fatchan, Soekamto, Amirudin, and Nudia. 2016). Thus, the findings of this study complements previous research findings on the influence of tradition (local wisdom) that are "sacred" to the behavior of the public.

\section{Conclusion}

First, the public believes Bulukumba District maintain forests is an obligation. This was in line with the tradition of Pasang Ri-Kajang. Where the forest is an area that is holy, sacred, and have supernatural powers. Bulukumba society in their communal life very obedient to Ammatoa. They know and understand the three types of forest that grouping karamaka, batasayya, and luarayya. The third grouping the forest types are not differentiated on the type of tree that is in it, but more emphasis on the sanctity of which is owned by the forest. Second, community actions treats forests as: karamaka (sacred forests or protected forests), batasayya (limited production) and luarayya (community forests). The pattern of such acts are influenced by their kasipalli (prohibition destroying forests). If there is a violation, then sanctioned and banned from customs by Ammatoa. As a result of the application of the tradition and the rules consistently, then the forest in 
Bulukumba be stable until now. If people commit a violation, the sanctions are implemented is customary: Cutting down trees in the forest karamaka sanctioned "the base of the whip", a fine of Rp. 800,000, plus a roll of white cloth; Cutting down trees in the forest were awarded a penalty battasayya middle "whip", a fine of Rp. 400,000, coupled with a white cloth roll; Cutting down forests luarayya sanctioned punishment "tip of the whip", a fine of Rp. 200,000 and a roll of white cloth. Even if there is a violation of the unknown culprit, carried out in the form of ritual ceremonies to unveil the truth namely: Attunu panroli (burning "crowbar") and Attunu Passau (burning "incense"). The ceremony was intended to reveal the meaning of truth, honesty, and trust in the people's daily life.

\section{References}

Adhan. 2005. Community Value System Ammatoa. Makassar: Published Pustaka Reflection.

Ahmad, S. 2007. Education and Indigenous Belief Systems Ammatoa. Makassar: Published Pustaka Reflection.

Akib. Y. 2003. Human Images Kajang. Makassar: Published Pustaka Reflection.

Arief, A. 2001. Forests and Forestry. Yogyakarta: Published Kanisius.

Aryadi. 2000. Saving Time Forests in Indonesia. Jakarta: Yayasan Obor Indonesia.

Belinda. 2012. Teaching Practice in a Darug Classroom: How Teachers can Build Relationships with an Aboriginal Community Outside the School. Australia. The Australian Journal of Indigenous Education. Vol.41, Issue 02, December 2012. (pp139-145)

Bromley, D. B. 1989. Making the commons work (Ed). San Francisco, CA: Institute for Contempory Studies.

Fatchan, Ach. 2013. Qualitative Research Methods: Qualitative Research 10 Step Approach Construction and Phenomenology. Malang: UM Press.

Fatchan, Ach; Ach. Amirudin; dan Hadi Soekamto, 2015. Education Model "Bandongan" for Farmers Society of Agricultural Skills Training in the Background of Sosioculture "Pesantren" in East Java. Mediterranean Journal of Social Science. MCSER Publishing, Rome-Italy. ISSN 2039-2117 (online) ISSN 2039-9340 (print)Vol 6 No 5 September 2015. Doi:10.5901/mjss.2015. v6n5p515

Fatchan. Ach; Hadi Soekamto; and Mustafa. 2015. Defections "Kiai", "Ustadz" and Farmers In The New Order and The Reform Order In The Islamic Tradition In Rural East Java. Journal of Culture, Society and Development. Vol.5, No. 10 (2015). ISSN (Paper). 2224-5766 ISSN (online) 2422-8400. International Istitute for Science Technology and Education.

Fatchan, Ach; Hadi Soekamto; Ach. Amirudin; dan Alifia Nudia. 2016. Understanding Behaviour Environmental Education Water Resources Model of Outdoor Study on Community of "Osing" at Banyuwangi District East Java Indonesia. Research on Humanities and Social Sciences. ISSN (Paper)2224-5766 ISSN (Online)2225-0484 (Online) Vol.6, No.6, 2016. www.iiste.org.

Forest Watch Indonesia. 2015. Images of the Forest Indonesia Period 2009-2014. Bogor: Forest Watch Indonesia.

Geertz. 1992. Values and Ethics. Jakarta: PT Gramedia Pustaka Utama.

Hidayat. 2010. Bringing Values Education. Bandung: Alfabeta

Ibrahim. 2001. Community Ammatoa in Preservation of Forest Resources. Makassar: Published Pustaka Reflection.

Keraf, S. A. 2002. Environmental Ethics. Jakarta. Published by PT. Kompas Media Nusantara.

Law of the Republic of Indonesia Number 41 Year 1999 on Forestry.

Lureng, G. 1991. Install Ri Kajang: An Approach From the aspect of Anthropology. Makassar. Published Pustaka Reflection.

Miles and Huberman. 1992. Qualitative Data Analysis. Jakarta. University of Indonesia (UI-Press)

Ministry of Forestry. 2012. Forest Management Policy. Jakarta

Ministry of Environment. 2004. Environmental Education Policy. Jakarta the Republic of Indonesia

Qandhi. 2012. Education, Culture and Civil Society of Indonesia. Bandung. Published by PT Pemuda Rosdakarya.

Ramli. 2012. Human and Peoples Culture Kajang. Makassar. Published by Pustaka Reflection.

Salim. 2014. Development and Maintenance Environment-Based Local Wisdom. Yogyakarta. Published by Pustaka Pelajar.

Sumarmi and Amirudin. 2014. Environmental Management Based Local Wisdom. Malang. Aditya Media Publishing.

Susilo, Suko and Fatchan, Ach. 2014. The Comparation Social Change Community Farmers in the Village Islamic Boarding School Beckground. Journal of Geography and Education. Th 19 No. June 2, 2014. ISSN 0853-9251 (pages 15-32) Malang. Department of Geography-FIS State University of Malang.

Usop, 1998. Replace Ri-Kajang. Assessment System Value At Fort Black Ammatoa. Research Training Center Social Sciences: Ujung Pandang, Indonesia.

Yakib. 2003. Ammatoa, Community in Black. Makassar: Published by Pustaka Reflection. 